\title{
Cerebral Proliferative Angiopathy-Description of a Rare Clinical Entity
}

\section{Angiopatia cerebral proliferativa - descrição de uma entidade clínica rara}

\author{
Pedro Radalle Biasi ${ }^{1}$ Timóteo Abrantes de Lacerda Almeida ${ }^{1}$ Rafael Augusto Espanhol ${ }^{1}$ \\ Matheus Pintos Brunet ${ }^{1}$ Paulo Sérgio Crusius ${ }^{2}$ Adroaldo Baseggio Mallmann ${ }^{2}$ \\ Cláudio Albano Seibert ${ }^{2}$ Marcelo Ughini Crusius ${ }^{2}$ Charles André Carazzo ${ }^{2}$ Cassiano Ughini Crusius ${ }^{2}$ \\ ${ }^{1}$ Resident, Institute of Neurology and Neurosurgery, São Vicente de \\ Paulo Hospital, Passo Fundo, RS, Brazil \\ 2 Neurosurgeon, Institute of Neurology and Neurosurgery, São \\ Vicente de Paulo Hospital, Passo Fundo, RS, Brazil \\ Address for correspondence Pedro Radalle Biasi, MR, Av. Sete de \\ Setembro, 65, apto 101, CEP 99010-121, Passo Fundo, Rio Grande do \\ Sul, Brazil (e-mail: pedrobiasi@doctor.com).
}

Arq Bras Neurocir 2015;34:82-85.

\section{Abstract \\ Keywords \\ - arteriovenous malformations \\ - cerebral angiography \\ - embolization}

\section{Resumo}

The cerebral proliferative angiopathy (CPA) is an uncommon vascular malformation of the brain, representing approximately $3.4 \%$ of arteriovenous malformation (AVM) cases, with complex morphology and poorly understood origin. Thus, we present the case of a woman patient aged 27 years, who performed magnetic resonance imaging (MRI) of the brain because of a headache. Extensive malformation was identified vascular right frontoparietal, with the presence of the brain tissue mixed with the vessel. CPA identified multiple feeder arteries, with the absence of nidus and slowing the flow into the venous system, confirming that it was CPA. During evaluation at another hospital she underwent partial embolization of the lesion, without success. Currently, the patient is progressing with left hemiparesis. CPA has distinct characteristics, such as large dimensions, presence of functional brain tissue intermingled with the vessels, no nidus, multiple nourishing vessels, and small veins. It does not present well-defined nidus or flow-related aneurysms. These characteristics classify it as a disease itself within the group of AVMs. This case clinically presents with seizures, refractory headaches, focal neurologic deficits, and low risk of bleeding. Alternatives for curative treatment imply significant neurologic deficits and the most accepted options aimed at easing the symptoms and the partial embolization alternative that is best associated with risks and benefits.

A angiopatia cerebral progressiva (ACP) é uma malformação vascular encefálica incomum, representando cerca de 3,4\% dos casos de malformações arteriovenosas (MAV's), com morfologia complexa e origem pouco compreendida. Assim, apresentamos o caso de uma paciente de 27 anos, que realizou RNM de crânio para investigação etiológica de cefaleia, tendo sido identificado extensa malformação vascular frontoparietal direita, com a presença de tecido cerebral entremeado aos vasos. Exame de received

January 1, 2014

accepted

November 1, 2014
DOI http://dx.doi.org/

$10.1055 / \mathrm{s}-0035-1547393$. ISSN $0103-5355$.
Copyright $(2015$ by Thieme Publicações License terms

Ltda, Rio de Janeiro, Brazil
(1) $\Theta \circledast$ 


\section{Palavras-chave}

- malformações arteriovenosas

- angiografia cerebral

- embolização terapêutica angiografia cerebral identificou múltiplas artérias nutridoras, com ausência de nidus e lentificação do fluxo para o sistema venoso, confirmando tratar-se de Angiopatia Cerebral Proliferativa. Durante avaliação em outro serviço foi submetida à embolização parcial da lesão, sem sucesso. Atualmente a paciente vem evoluindo com hemiparesia dimidiada à esquerda. A ACP apresenta características distintas como a presença de tecido cerebral funcionante entremeado aos vasos, ausência de nidus, múltiplos vasos nutridores e pequenas veias, sendo uma lesão de grandes dimensões. Não apresenta nidus bem definido ou aneurismas relacionados ao fluxo. Estas características a classificam como uma doença própria dentro do grupo das malformações arteriovenosas. Clinicamente cursa com crises epilépticas, cefaleias refratárias e déficits neurológicos focais. Apresenta baixo risco de sangramento. As alternativas para tratamento curativo implicam em importantes déficits neurológicos e as opções mais aceitam visam à atenuação da sintomatologia, sendo a embolização parcial a alternativa que melhor associa riscos e benefícios.

\section{Introduction}

The cerebral proliferative angiopathy (CPA) is an uncommon vascular malformation of the brain, with complex characteristics and poorly understood origin. A patient presents with characteristics such as large dimensions, multiple feeding vessels, small veins, and normal brain tissue warehouse. ${ }^{1-3}$ It is classified as a disease itself within the group of arteriovenous malformations (AVMs). ${ }^{4}$ Alternatives for curative treatment imply significant neurologic deficits and accept more options aimed at easing the symptoms. ${ }^{1,2,4}$

\section{Case Report}

Female patient, 27-year-old, performed a brain magnetic resonance imaging (MRI) for investigation of headache, showing AVM, with the presence of brain tissue mixed with the anomalous vessels and a surrounding edema. CPA found no dominant feeder vessel and slow flow into the venous system, confirming that it was CPA. During evaluation at another hospital she underwent partial embolization of the lesion, without success. Currently, the patient performs clinical follow-up, and she began to present left hemiparesis after 5 years of follow-up.

\section{Discussion}

The CPA is a congenital condition, resulting from an abnormal development of the brain vessels and, like other AVMs, is poorly understood. ${ }^{2,5}$ The largest series of cases concerning this entity found a prevalence of $3.4 \%$ among all AVMs, which, in turn, affect 0.01 to $0.5 \%$ of the world population, which indicates the rarity of this pathology. ${ }^{4} \mathrm{CPA}$ can occur in any brain area, but has a predilection for the "watershed zone." The involvement of cortical areas in isolation is unusual. ${ }^{4}$

Clinically, CPA courses similar to other MAVs with seizures, debilitating headaches, and progressive neurologic deficits, mimicking strokes. ${ }^{1,2,4,6}$ The risk of hemorrhage, regardless of what happens in other vascular malformations, is small, occurring in approximately $12 \%$ of cases, however, with risk of rebleeding of $70 \%$, probably due to extensive vascular proliferation. ${ }^{1,2,4,6}$ Despite the severity of these diseases, many patients remain asymptomatic throughout life, contributing to the poor understanding of this disease. ${ }^{2}$

The morphology of the CPA is unique and an important point for the distinction with MAVs and hemangiomas. Though AVMs are dilated and tortuous vessels, with direct communication between arteries and veins and the presence of a large feeding artery, the ACP is characterized by its large size, with multiples feeding vessels, without a welldefined nidus, with drainage being made by small ectatic veins, and, most important, the presence of functioning brain tissue interspersed between the anomalous vessels. There is no dominant feeding artery or flow-related aneurysms. ${ }^{1-5}$ Hemangiomas also enter the differentiation toward ACP for presenting components of endothelial proliferation, being proposed by Eesa et $\mathrm{al}^{1}$ that the CPA would be an intermediate lesion between the MAVs and hemangiomas.

Some cerebral angiomatous syndromes should be investigated in the course of diagnosis of CPA, as Rendu-OslerWeber, Sturge-Weber, Wyburn-Mason (brain-retino-facial angiomatosis), and mainly Moya-Moya diseases. ${ }^{2}$

Computed tomography (CT) and MRI are useful in the diagnosis by revealing anomalous brain tissue mixed with a diffuse vascular network ${ }^{4}$ ( - Fig. 1A,B). Perfusion MRI shows increased flow in the center of the lesion, with increased mean transit time, indicative of capillary ectasia, and an area of hypoperfusion that may affect distant sites. ${ }^{3,4}$ On angiography it is possible to identify multiple feeding vessels by allocating the malformation ( $\mathbf{- F i g}$. $\mathbf{2 A}, \mathbf{B}$ ). The center of the lesion is poorly delimited with flocculated appearance and size varying between 3 and $6 \mathrm{~cm}$, with viewing areas of angiogenesis. The blood flow is high for the central area, but the transition to the venous system is slow, occurring 

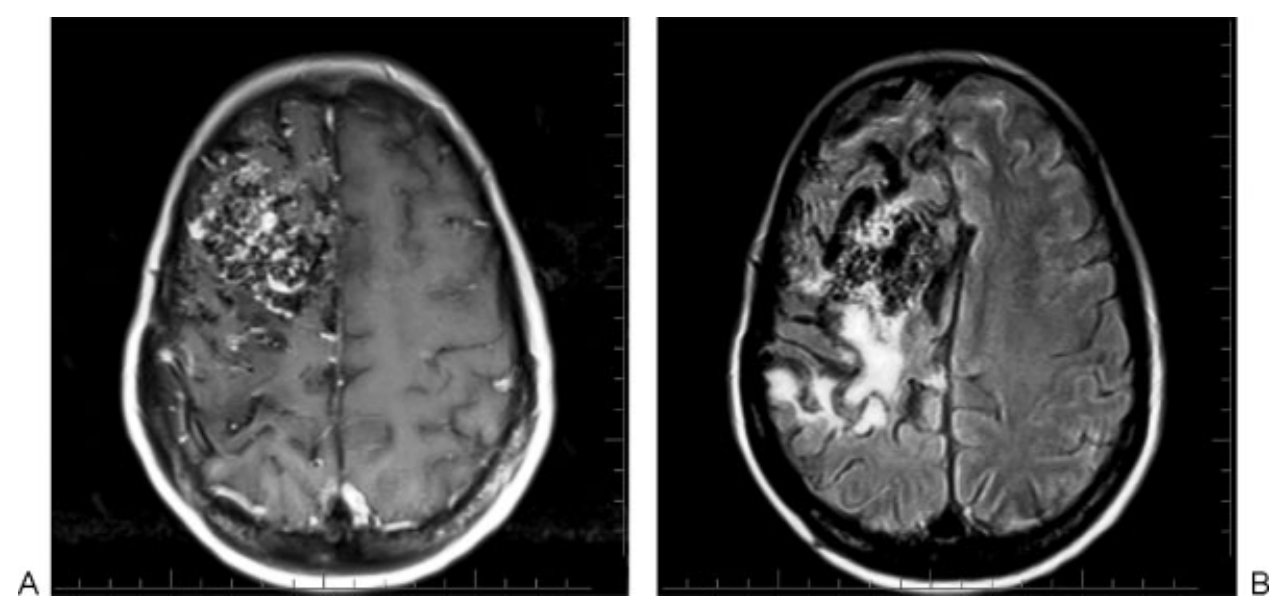

Fig. 1 Axial MRI shows the anomalous vessels with brain tissue intermingled on T1W sequence with contrast (A), and the large feeding arteries and surrounding edema on FLAIR (fluid-attenuated inversion recovery) (B).
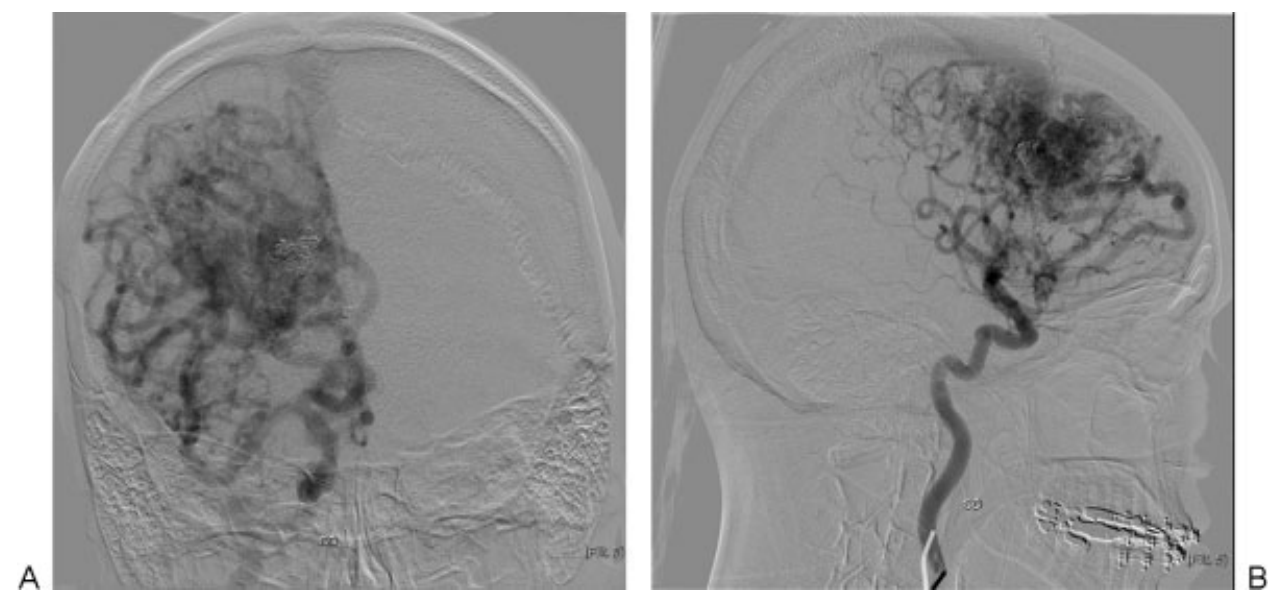

Fig. 2 Digital subtraction angiography on anteroposterior (A) and lateral (B) views shows multiples feeding arteries, no defined nidus, and the onyx of preview embolization.

formation of true lakes of contrast surrounding edema, attesting the existence of capillary ectasia. $2,4,6,7$

The slowing of the flow due to capillary ectasia causes ischemia of perilesional tissue and even the adjacent cortex, which trigger a progressive and uncontrollable angiogenic stimulus and perpetuate the angioproliferative process. ${ }^{1,2,4,7}$ Some studies have shown the occurrence of transdural supply, also abnormal, and directed both the malformation and the adjacent cortex. ${ }^{4}$ These characteristics led to the use of the term "proliferative."

Histopathologic analysis of the vessels shows abnormal lamination at the internal elastic lamina and muscle fibers in the arterial bed and increased collagen deposition in the venous bed. In subendothelium there is increased amount of type IV collagen. Brain tissue present between the vascular beds may present gliosis. ${ }^{4,6}$

The distinction between CPA and MAVs become of paramount importance in the treatment, as each must be handled differently. ${ }^{1,4,6,7}$ Surgical treatment, both in the conventional manner as in radiosurgery, presents the risk of permanent damage to the functioning parenchyma intermingled to injury, especially in cases of eloquent areas, being reserved for cases of intractable headache and seizures. ${ }^{1,2,4} \mathrm{~A}$ endovascular approach, with complete embolization of the lesion, as well as technically difficult, causes the same damage as an excisional surgery, as normal brain tissue is embolized together. For cases of debilitating and uncontrollable headache, partial embolization of the malformation in noneloquent areas can produce significant improvements. ${ }^{1,2,4}$ Another viable option is to perform calvarial burr holes that increase cortical blood flow by recruiting dural flow and inhibiting the mechanism of angiogenesis due to ongoing ischemia, so it may contain disease progression, in addition to alleviating symptoms. ${ }^{2,4}$

Thus, it is evident the importance of knowledge about the CPA, placing it in the differential diagnosis of AVMs and hemangiomas, once the natural history differs and therapies capable of carrying imply significant risks for patients.

\section{Conflicts of Interest}

The authors declare no conflict of interest. 


\section{References}

1 Eesa M, Sharma P, Goyal M. Cerebral proliferative angiopathy. Can J Neurol Sci 2009;36(2):242-243, discussion 135

2 Dória-Netto HL, Souza-Filho AM, Dória-Netto RH, et al. Cerebral proliferative angiopathy. Arq Neuropsiquiatr 2010;68(2): 300-302

3 Ducreux D, Petit-Lacour MC, Marsot-Dupuch K, Bittoun J, Lasjaunias $P$. MR perfusion imaging in a case of cerebral proliferative angiopathy. Eur Radiol 2002;12(11):2717-2722

4 Lasjaunias PL, Landrieu P, Rodesch G, et al. Cerebral proliferative angiopathy: clinical and angiographic description of an entity different from cerebral AVMs. Stroke 2008;39(3): $878-885$

5 Chin LS, Raffel C, Gonzalez-Gomez I, Giannotta SL, McComb JG. Diffuse arteriovenous malformations: a clinical, radiological, and pathological description. Neurosurgery 1992;31(5):863-868, discussion 868-869

6 Fleetwood IG, Steinberg GK. Arteriovenous malformations. Lancet 2002;359(9309):863-873

7 Srivastava T, Mathur T, Jain R, Sannegowda RB. Cerebral proliferative angiopathy: a rare clinical entity with peculiar angiographic features. Ann Indian Acad Neurol 2013;16(4):674-675 